\title{
Overview of Bonus (Amendment) Act, 2015
}

\author{
G. Gopalakrishnan ${ }^{1}$, Dr. G. Brindha ${ }^{2}$ \\ ${ }^{1}$ Research Scholar, Depart of Management Studies, Bharath University, Selaiyur. Chennai-73, India \\ ${ }^{2}$ Research Supervisor, Depart of Management Studies, Bharath University, Selaiyur. Chennai-73, India
}

\begin{abstract}
Bonus is paid based on profit earned by the company during the financial year. However, minimum bonus of 8.33\% was assured irrespective of profit earned or not. While so, the maximum bonus is fixed at $20 \%$ and the balance is carried forward as "set-on" to cater the emergency for next years. In recent amendment, the bonus increase was declared retrospectively. Once the bonus is paid based on profit, after negotiation with employee's representative, making it retrospective will make additional burden on employer. Therefore, the same is not fair and stay on retrospective effect is granted by Karnataka, Madras and few other High Courts. In addition, the bonus calculation is linked to Minimum wage. Since, the minimum wage differs from state-to-state; within the state zone-to-zone and industry-to-industry, bonus payment based on minimum wage will not be uniform within the state, region and industry. Therefore, linking of minimum wage act with bonus act will lead to disputes in the industry.
\end{abstract}

Keywords: ventricular noncompaction, spongiform cardiomyopathy

\section{Introduction}

History of bonus can be dated back to Word War I, 1914 1918 when the mill owners of west India paid "War Bonus". Gradually, the right of the workers to receive bonus out of the profit made by the employers was recognized and subsequently adjudicated. The first dispute on bonus was raised in 1948 by Bombay Textile industry. Labour Appellate Tribunal in Mill Owners Association vs. Rashtriya Mazdoor Sangh in 1952 laid down full bench formulae for Payment of Bonus to workers.

In ACC Ltd vs. Its workmen case, the Supreme Court suggested that a rule for consolidating and codifying the law for payment of bonus could be enacted. Subsequent to this, Government of India formed a "Bonus Commission" in 1961. The Bonus Commissions, in $\mathrm{t}$ is report pointed out that "it is difficult to define concept of bonus in rigid terms but it is possible to insist that once the profit exceeds certain limit, labour will legitimately have a share in the profit earned. Bonus commission in essence was referring only to "profit sharing bonus". In 1965 an order was passed by the parliament, which provided payment of bonus to employees employed in certain establishment. The Payment of bonus act replaced this 1965 ordinance and received the approval of the President on $25^{\text {th }}$ September 1965.

\section{Dimensions}

The scheme of Payment of Bonus act broadly stated in four dimensional(1) :-

a) To impose statutory liability on employers to pay bonus

b) To define principle of payment of bonus according to prescribed formula

c) To provide minimum and maximum bonus and link-it with set-on and set-off

d) To provide machinery for enforcement of liability for payment of bonus

\section{Amendments}

Since our concern is related to "The Payment of Bonus (Amendment) Act, 2015 limiting the scope only with sec 2 (13), sec 12 of the payment of bonus act, 1965 and its effective date.

As far as above mentioned sections concerned the act is amended 4 times:

\begin{tabular}{|c|c|c|c|}
\hline$\underline{\text { Year }}$ & $\underline{\text { Sec 2(13) }}$ & Sec 12 & Effective date \\
\hline 1965 & Rs. 1600/- & Rs. 750/- or actual whichever is less & - \\
\hline 1985 & Rs. 2500/- & Rs. 1600/- or actual whichever is less & - \\
\hline 1995 & Rs. 3500/- & Rs. 2500/- or actual whichever is less & - \\
\hline 2007 & Rs. 10,000/- & Rs. 3500 or actual whichever is less & 1 Apr 06 \\
\hline 2015 & Rs. 21,000/- & $\begin{array}{c}\text { Rs. 7000 or the minimum wage for the scheduled employment, as fixed by the } \\
\text { appropriate government, whichever is higher }\end{array}$ & 1 Apr 14 \\
\hline
\end{tabular}

The recent amendments are :

It shall be deemed to have come into force on the $1^{\text {st }}$ day of April, 2014 and

Sec 2 (13) : for the words "three thousand five hundred rupees" at both the places where they occur, the words "seven thousand rupees or the minimum wage for the scheduled employment, as fixed by the appropriate government, whichever is higher" shall respectively be substituted.
The strings attached in recent amendments are :

The strings:

a. effective date

b. rupees seven thousand or minimum wages prescribed by appropriate government, whichever is higher.

a. effective date: As far as effective date is concerned, reference is made to the Supreme Court judgement on Remington Rand of India ltd vs the workmen wherein it was clearly stated that bonus act cannot be applied

\section{Volume 5 Issue 2, February 2016}




\section{International Journal of Science and Research (IJSR) \\ ISSN (Online): 2319-7064}

Index Copernicus Value (2013): 6.14 | Impact Factor (2014): 5.611

retrospectively (2) Normally the bonus is calculated based on Profit \& Loss of the company. Therefore, for the financial year $2014 \sim 2015$ based on P\&L, through collective bargaining process the bonus $\%$ was agreed and already paid in Oct/Nov 2015. In the bonus draft bill which was passed by parliament, the effective date mentioned was $1^{\text {st }}$ April 20153), therefore, employers were not concerned because the revised bonus was effective from financial year 2015 2016. Whereas, in the gazette signed by the President of India, the effective date mentioned is $1^{\text {st }}$ April 2014(4).

Since the bonus \% is fixed and paid in Oct/Nov 2015, making it effective retrospectively, will reopen the issue which were amicably settled after a long fight between the employer and employees. Since the bonus was paid on P\&L, reopening of the issue will certainly involve additional illogical financial burden to employers, and the employers through their forum / federation is likely to challenge the amendment. Hence the effective date (retrospective) needs to re-considered.

b. rupees seven thousand or minimum wages prescribed by appropriate government, whichever is higher : it has two parts i.e. i. "linking the minimum wage with bonus" and ii. "Whichever is higher". Let us discuss one-by-one

\section{i. Rupees seven thousand or minimum wages prescribed by appropriate government}

The expected effects under this amendment could be:

In the original act as well as previous amendments it use to refer only the bonus act, no other act was clubbed, therefore, the act retained its originality. In recent amendment, the Minimum Wages act is inserted. By insertion of Minimum wages act, the bonus act is expected to lose its originality in the long run, because the minimum wage is fixed based on Consumer Price Index and revised annually. Since the minimum wage is increasing annually, this will exceed the amount fixed by bonus act under sec 12 and there will be no need to amend or to look at sec 12 of the payment of bonus act 1965 in future, alternately, sec 12 will have no meaning and likely to become obsolete. Minimum wage includes, Basic, Dearness Allowance and House Rent Allowances and ratio of bifurcation of minimum wage among the three components is not defined anywhere in the law. Therefore, employer can split minimum wage as per his convenience, which may result into industrial conflict.

Recent judgement / Tribunal orders clearly state that employer has all right to split the minimum wage for the purpose of Employee Provident Fund(5. Normally an employer has uniform Basic. DA, HRA etc, cannot have different Basic, DA, HRA for Provident Fund and different for Bonus act. In addition Basic and DA will affect other related laws like Gratuity Act, Employee Compensation Act, Maternity Benefit Act etc. Therefore, insertion of Minimum wages act in amendment will invite litigation.

\section{ii. Whichever is higher}

The most taxing word in the amendment, because:-
Present minimum wage is Rs. 7400 in Tamil Nadu, and crossing Rs 10,000 in certain northern states of India. Certainly in another few years, even after bifurcation, the Basic + DA under minimum wage will cross Rs. 7000/- set by the Bonus (amendment) act for calculation purposes. Once the minimum wage crosses Rs. 7000 set by bonus act $\mathrm{u} / \mathrm{s} 12$, will over ride section 12 of the bonus act.

Under the above said circumstances, minimum wage is not uniform among the states or among the industry within the state or among the zones within the state or among the cadre. Therefore, there will be no uniformity of bonus among the state/industry/zone/cadre, which will again lead to unrest.

Multi National Companies or the Industries having branches in different states of India will have no uniformity in payment of Bonus among its employees across the country; certainly will lead to heavy heart burns among employees of the same employer.

\section{Conclusion}

Majority of the employers represented through their forums / associations feel that bonus for the financial year based on $\mathrm{P} \& \mathrm{~L}$ is negotiated and paid in Oct/Nov 2015. Therefore, effective date of $1^{\text {st }}$ April 2015 as mentioned in Draft Bill No. 265 of 2015 may be retained.

Employees and their unions feel that Minimum wage is revised annually, there is no standardized minimum wage among the states / zones within the state/ industries of same locality, and there will be no uniformity of bonus. Therefore, insertion of minimum wages act in bonus (amendment) act, 2015 may be reviewed.

HR professionals opine that bifurcation of minimum wage is allowed but their proportion / percentage is not defined anywhere in the law. In absence of such guideline, employers may bifurcate as per their convenience, in order to get maximum benefit; employees may approach their unions, which will lead to more and more disputes. Therefore, usual wording under sec 12 of payment of bonus act, 1965 i.e. "whichever is less" may be reconsidered.

Management consultants feel that, paying $8.33 \%$ of actual Basic + DA, ignoring minimum wage may solve the issues. But, paying $8.33 \%$ on actual will cause heavy financial burden to employers and also sec 12 of payment of bonus act will lose its presence in the long run.

\section{References}

[1] M/s. Jalan Trading Company pvt ltd v Mill Mazdoor sabha, AIR 1967, Supreme Court, 691

[2] Remington rand of India vs the workmen. 1970 AIR 1421, 1970 SCR (2) 935, 1969 SCC (3) 913

[3] The Payment of Bonus (Amendment) Bill, 2015 Bill No. 265 of 2015

[4] The Payment of Bonus (Amendment) Act, 2015 No. 6 of 2016 dated $31^{\text {st }}$ Dec 2015

[5] ATA 743 (8) 10 decided on $30^{\text {th }}$ Nov 2015 